\title{
O PODER DO CANTO
}

\author{
Donaldo Schüler \\ (UFRGS)
}

Résumé

Pour commencer, chantons les Muses Héliconiennes, reines de l'Hélicon, la grande et divine montagne

(trad. P. Mazon)

Qui est-ce qul chante? - Tout le monde et personne. Les chanteurs et les auditeurs. Le Podte et nous-mêmes. Personne.

Quand est-ce qu'on chante? - On chante pour commencer. Et le chant des Muses cherchera les fondements de l'Univers.

Les Muses progressent de l'ombre vers la lumière sur le chemin de la découverte. Elles nous annoncent, nuit et jour, une histoire de victoires et de défaites, de Dleux valnqueurs et de Divinités vaincues. Elles nous font sentir tout ce qu'll y a de civilisalion et de sauvagerle dans notre monde; elles nous font voir tout ce qu'il y a sur la terre et dans les profondeurs du vide; elles nous font entendre et la volx et le silence.

A vrai dire, le chant c'est la volx des Muses. Le langage leur appantient: le langage ordonné, loglque, rationnel. Rien de ce qu'on peut voir - et entendre - aujourd'hul; rien de ces impressions passagéres qui se confondent avec les souvenirs l'enlance; rien de ces temps chaotlques, de ces hommes brisés qui nous entourent: rien de ce désordre où nous sentons irrémédiablement (?) noyés, et où nos poètes cherchent leurs pauvres muses en morceaux. 


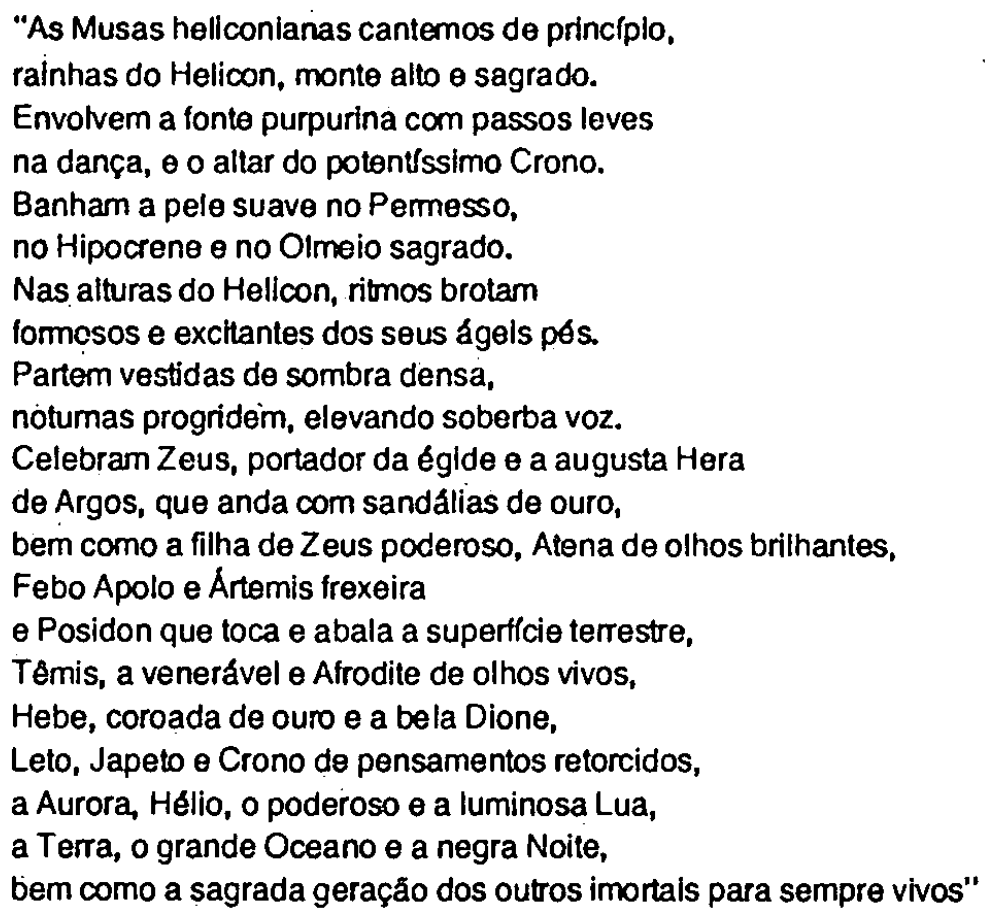

(Teogonia, 1-21).

Quem canta? Todos e ninguém. Todos çantam. O nós implícito na desinência do verbo tanto pode ser o plural majestático de proeminentes mandatários como pode exprimir a fingida humildade dos que atraem, no discurso, a atençăo das multid̋̃es a serem conduzidas. Nos pode ser, ainda, eu mais os semelhantes, outros pastores, outros poetas. Năo convém esquecer o eu inserido na coletividade dos cidadăos. Neste caso, o canto imana cantor e ouvintes na mesma empresa. Importa reter todas as possibilidades. A palavra poética recolhe, com freqüência, feixes de significaçర̋es. Elas definem bem o cantor da Antiguidade investido de poder - não importa o estrato social de que proceda - e integrado na coletividade, em significativo contraste com o poeta moderno, enfraquecido e solitário.

Ninguém canta. O canto soa como a voz das Musas (soberanas, divinas, distantes) de que os poetas săo acidentais portadores. Como a voz das Musas é a de sempre, náo cabe ao poeta propor novos ritmos ou intervir na seleçăo das palavras. O poeta, na opiniăo generalizada; canta como embriagado, como em extase.

Numa época conflituada como a de Hesiodo, em que parte significativa da populaçăo vive à margem do conforto, espoliada pelos prósperos donos de terra, o Hélicon das Musas seduz com sonhos paradislacos. Lá a vida transcorre tranqülla na vizinhança de águas em que se espelham as coloridas corolas das flores, lá trabalho nenhum interrompe canto $\theta$ dança.

O que se canta? As Musas. Elas figuram, portanto, como sujelto e objeto do canto. O elevado número de cento e quinze versos a elas consagrado $\theta$ excepcional. Em poemas longos como a lllada e a Odisséía esgota-se breve a referência a elas. 
A Teogonia oferece, portanto, campo fecundo à reflexăo sobre o papel que representam. Elas cantam e sáo cantadas. O canto se apóla, assim, autonomo e soberano, em si mesmo sem buscar a autoridade em outra instáncla, seja autor, seja referente, seja privilegiada execuçăo. O canto, sendo o das Musas, náo requer outra validaçăo.

Cantemos de principio (arkhometh aeidein - arkhometh derivado de arkhe, principio), sugere sentido cronológico, hierárqulco e ontológico. O soberano canto das Musas, que agora príncipia, buscará os fundamentos do universo. Também a natureza aquática das Musas as situa no fundamento, visto que da água, já em Homero, nasce o Universo.

Heslodo, como se verá, nega ao Oceano a centralidade que lhe conferiu o autor da IIfada Restam, entretanto, os seus indicios. Com as Musas, fazem-se aquáticas agora as palavras, como se farăo lgneas em Heráclito. O poema apresenta superficle úmida, mesmo quando năo canta divindades ligadas a mares e rios. Fluindo como as correntes, as Musas ligam uns acontecimentos a outros. Insinuando-se em território seco, vitalizam, movimentam o que, sem elas, se imobilizaria.

Visto que no desdobramento do universo o dia nasce do escuro ventre da Noite, as Musas progridem da sombra para a luz na marcha do continuo desvendamento. Ao ritmo da dança, o mundo desperta rico e variado no frescor das origens. As Musas anunciam uma história de vitórias e derrotas, deuses que ascendem e divindades banidas, noite e dia, atraçăo e repulsăo, civilização e barbárie, superflcie e profundidade, palavra e silêncio. Os ritmos do canto e do cosmo confluem. O ritmo do canto se allmenta do ritmo do cosmo e o exprime. A vida que brota do seio da Terra atravessa a totalidade. O cosmo, ao se erguer do fundo sombrio donde tudo procede, ingressa na guerra dos contrários. Antes do ritmo, germinam os possiveis, o: silêncio antes da voz, a sombra antes da luz. O ritmo preside a dança do desvelamento, os passos do oculto ao revelado.

A dança $\theta$ a linguagem do corpo. Na dança o corpo esplende em liberdade. Antes e depois do trabalho, a dança revela o corpo em inventivas possibilidades. A dança reconquista a liberdade aos membros presos a fins precisos no decurso da execuçăo de tarefas. O canto refaz o percurso do universo na trajetória das revelaçठ́es.

As Musas cantam e dançam. O ritmo se une ao mito. $O$ mito constrol a ordem verbal. O rito organiza os movimentos do homem $\theta$ do mundo.

As Musas estăo ligadas a montes, a fontes, $\theta$ é admirativo o tom do Poeta. A natureza o chama ao canto. Chama-o de longe porque a admlraçăo abre distâncias. Como vencê-las sem o auxflio das Musas? Perdido está o contato diretto com as coisas. Entre o cantor $\theta$ o cantado, estende-se o úmido véu dos versos, tecido pelas deusas. As Musas sấo detentoras da linguagem. De toda a linguagem. Cantando, velam $\theta$ desvelam. Revestida pelo canto, intocável se rëtral a pele das colsas. Náo fossem as Musas, outro sistema verbal the tomaria o lugar. Por náo podermos reaproximar o que definitivamente se perdeu, lançamos pontes sobre ablsmos. Sendo frágeis, mostram-se prestes a ruir, convocando outros engenheiros. Ponte nenhuma, por estável que seja, pode requerer o privilégio de última. 
O poeta canta as Musas que celebram. Temos duas camadas verbals ligadas a uma terceira. A realidade mesma esconde-se atrás dos nomes. Ao tecermos o comentário sobre o poema, introduzimos a terceira camada. Estamos em pleno dominio da produtulidade textual. Os textos se unem e geram em procraçáo infinita.

Visto que as Musas o celebram, Zeus Ihes deve a existéncia. Nada o ampara fora da celebraçåo. Observado assim, Zeus ó filho das Musas de quem é pal. Em lugar do Oceano homérico, origem de todos os deuses, comparecem as Musas. O mundo alnda tinha centro. Zeus era o centro, embora ameaçado. Morto Zeus e năo havendo rilnguém que the tome o lugar, ficamos com o puro jogo verbal da modemidade, expresso nos versos de Baudelaire, Mallarmé e Pessoa.

$\mathrm{Na}$ Teogonia, o canto se abisma do presente no passado em busca do fundamento. Náo se trata da fuga do presente, mas de sua fundamentaçăo. Como o sentido do fundamento se deriva do presente, este ficaria suspenso no sem-sentido, privado do apolo que a origem the confere.

As palavras, nascidas do generoso corpo das Musas, atestam origem feminina como os mares e os montes, as florestas e os campos. As palavras guardam no ritmo e na modulação a seduçăo dos olhos que, no berço, as saudaram. Deuses franquelam o caminho porque estes săo os signos das Musas. Deuses sấo as correntes que engrossam o ro das Musas e através dele que se percebe o movimento das formas que se buscam. O presente 6 indicado pelo casal divino que no agora do Poeta detém o poder, Hera e Zeus. O póder do mandante supremo se exerce atraves de seus filhos: Atena (a sabedoria), Apolo (os desígnios secretos), Ártemis (o reino animal e vegetal) $\theta$ através do Irmăo submisso, Posidon, o rei dos mares.

O passado anterior comparece na mençăo de antigas esposas: Têmis (outrora protetora das leis), Dione (mãe de Afrodite numa das vertentes miticas), Leto (máe de Apólọ). Năo surpreende que, por expansáo associativa da memória, compareça, entre as deusas, Afrodite, responsável pela conjunção matrimonial, em companhia de Hebe. a deusa da juventude, ambas associadas, pela suas funçбés, ao casamento. $O$ passado remoto é lembrado com a menção dos Titãs Jápeto, pai de Prometeu, $\theta$ Crono, antecessor de Zeus. E chegamos às origens, base de tudo, nas apariçס̋es nomeadas depois de Aurora, Hélio e a Lua : a Terra, o Oceano e a Noite.

Al esta o Oceano, já filho da Terra ou ainda origem dela? Na dubiedade, ele permanece enigmaticamente ao lado dela. Hesído solucionará a dúvida mais tarde. Por agora, basta-lhe localizá-lo no princlpio, fonte dos rios e do aquoso em geral, incluindo as Musas.

Eis al o resumo da Teogonia O fato de năo ser caótica a enumeração, como em poemas recentes, mostra a intençăo ordenadora do Poeta. Tome-se um poema como "Nosso Tempo" de Drummond, e se verá o torvelinho de fragmentos desconexos. Impressరes passageiras do presente se misiuram com recordaçరes da infáncia sem que nexos significativos entre umas e outras possam estabelecer-se. Onde fol a ordem impera o partido, tempos partidos, homens partidos. A expertencla de desordern se confirma ao passarmos dal para "Tabacarla". de Fernando Pessoa. Al, somos agredidos 
pela oferta de artigos variados sem nada de essencial que os una. Deposto o Destino ou algo que o lembre, o acaso dispersa os objetos $\theta$ os atos de que se compoe a existência humana. No Waste Land, Eliot empenha-se, em văo, na tarefa hercúlea de socorrer as rulnas da cultura europeia. Adianta recolher fragmentos para recompor o todo quebrado em mil pedaços?

Vínculos rompidos, com os quais a modernidade nos familiarizou, repugnam ao pensamento mitico. Naqueles tempos, o vazio, presente na economia do universo, náo obsta o trânsito de um elemento a outro. O sentido permanecia assegurado em todos os percursos. Revestido de nomes divinos se apresentava o que hoje nos ameaça sem nome. Os espaços, cuidadosamente preenchidos pelas Musas, Impediam abalos, oferecendo chăo ao andar dos homens.

$\mathrm{Na}$ Teogonia, a organizaçåo do discurso traduz a ordem das coisas. O discurso decifra a realidade para que o homem se possa orientar nela. A narraçăo refaz o caminho da unidade. Esta se alcança na continuidade do narrar. A existéncia de vácuos romperia a unidade. A continuidade da narrativa corresponde ao fluir das águas, à continuidade do ser. O mito ráo apresenta provas, acompanha os acontecimentos na emergência. É nisso que reside a sua verdade.

O homem mitico vê mais do que aquilo que se oferece imediatamente aos sentidos. $O$ espetáculo oferecido năo se divide em casas $\theta$ bois $\theta$ árvores $\theta$ rios $\theta$ montes, dispersos e desconexos. A multiplicidade se agrega em conjuntos sutis, derivados de um principio comum, que imana a totalidade do observado.

Cada uma das partes é acolhida na luz da totalidade que as conecta $\theta$ ultrapassa, retraindo-se ao fundo que os sentidos năo percebem, mas que as Musas conhecem e preservam na comunidade dos homens através do canto. É dessas sombras, prenhes de luz, que as Musas procedem para iluminar o que se dispoe em torno dos homens. Elas abrem sendas para o que se adivinha além do imediatamente percebido.

Como nos sontos, Heslodo desce da experiência cotidiana ao oculto, ao soterrado pelos interesses e lembranças da vignia. Como nos sonhos, a infância, com os seus impulsos esquecidos e reprimidos, sobe à superficie.

Rememorar o passado significa passar do dominio de Zeus às forças por ele subjugadas, da ordem à organizaçăo em processo. O passado abre um espaço de crueldade e violéncia, um tempo que desejarlamos para sempre esquecido. Como nada morre, o passado é vivo e se insinua ameaçador na segurança presente. Ós outrós tempos, assim rememorados, sáo mais do que antecedente cronológico. Penetra-se no complexo tecido daquilo que $\hat{\theta}$, em busca da fonte de que tudo provém, o fundaménto que explique a totalidade. Indicado está o caminho ao pensamento fllosófico que virá depois. 